\title{
POLÍTICAS EDUCACIONAIS DO CAMPO: PERCURSO PRELIMINAR
}

\author{
Neila da Silva Reis \\ Universidade Federal do Pará (UFPA)
}

\begin{abstract}
RESUMO
O trabalho objetiva realizar um estudo da Política Educacional do Campo brasileiro no final do século XX e início do XXI. A metodologia concerne na análise documental. Os resultados apresentam um cenário sobre legislação educacional, de forma a pontuar decisões dos governos, procurando situar marcos, no que concerne aos seus princípios, objetivos e metas. São reivindicações e ações dos movimentos sociais do campo queconfiguram o debate por outra política educacional, que não seja embasada na lógica da racionalidade financeira e ausente da qualidade social, assim, evitar política parcial e fragmentada. Uma das conquistas é as Diretrizes Operacionais para a Educação Básica do Campo - CNE/CEB/Res. no 1, de 3/4/2002 e o Decreto 7.352, 2010, mas, a primeira não foi operacionalizada e nem chegou a ser formulada na maioria dos Estados. Com a elaboração do Projeto de Lei 8.035/2010, como está incluída a educação para as escolas do campo? Situar marcos e trajetórias, ainda que preliminarmente, é a primeira contribuição analítica, que revela, a encruzilhada de interesses privados e coletivos, em que se situa a educação brasileira. O estudo evidencia, que é necessário constituir aportes de resistência e intervenção, além de mecanismos legais, como leis, Diretrizes e decretos, que, não se limitam às metas e estratégias do PL 8.035/2010.

Palavras-chave: História e Educação,História das Políticas Educacionais, Legislação e campo
\end{abstract}

\section{FIELD OF EDUCATION POLICIES: PRELIMINARY COURSE}

\begin{abstract}
The study aims to conduct a study of the Educational Policy of the Brazilian countryside in the late twentieth and early twenty-first. The methodology concerns the analysis of documents. The results show a scenario on education legislation in order to point out the decisions of governments, seeking to locate landmarks, with regard to its principles, goals and objectives. Are claims and actions of rural social movements queconfiguram debate for another education policy, which is not grounded in the logic of financial rationality and absent of social quality, thus avoiding partial and fragmented policy. One of the achievements is the Operational Guidelines for Basic Education Field - CNE / CEB / Res. paragraph 1, of 04/03/2002 and Decree 7352, 2010, but the first was not operationalized and not even to be formulated in most states. With the drafting of the Bill 8.035/2010, is included as education for schools in the field? Locate landmarks and trajectories, although preliminary, is the first analytical contribution, which shows the intersection of private and collective interests, where it is the Brazilian education. The study shows, it is necessary to provide inputs for resistance and intervention, and legal mechanisms, such as laws, decrees and guidelines, which are not limited to goals and strategies PL 8.035/2010. Keywords: History and Education History of Education Policy, Legislation and field
\end{abstract}




\section{INTRODUÇÃO:}

As políticas públicas compreendem a dimensão da política inter-relacionada às demais dimensões como a social, cultural e econômica. Para compreender essas políticas, é necessário, conceber, a dimensão do trabalho como categoria fundante da reprodução humana, uma vez que as políticas sociais não devem ocorrer de forma emergencial e de curto prazo. O trabalho no contexto da forma capitalista de produção tem um fim não direcionado para aquisições da cultura humana; lógica esta que se remete para o trabalho educativo escolar.

A inversão da perspectiva atribuída, pelos setores dominantes, ao trabalhador - que produz a riqueza social,se revela, na forma como este é tratado e "incluído" no sistema, no sentido que assinala Germano (2005, apud MARX, 1975), como se esse trabalhador fosse um objeto, desqualificando sua força de trabalho.

A dimensão formativa escolar no contexto das políticas públicas do Estado Capitalista é decorrente das escolhas e decisões dos técnicos do Estado - em tensões e conflitos com setores da sociedade civil organizada -que sãoconstuintesdo processo histórico.

No contexto dos bens públicos, têm-se instrumentos legislacionais, entre esses, as Constituições, a LDB; outros também fazem parte deste conjunto para nortear a organização da vida pública e privada, como os Planos Nacionais, Estaduais e Municipais de Educação.Esses se constituem em elementos do sistema educacional e têm como principal objetivo contribuir a implementaçãoda Lei Nacional de Educação, no sentido de abranger e reunir pressupostos da política educacional, vislumbrando construir estratégias vinculadas ao cumprimento da referida lei. Para levar a cabo tais objetivos, de acordo com Saviani (2004), Frigotto e Ciavatta (2003), é necessário que os procedimentos na trajetória do processo ocorram na dimensão de uma relação democrática entre técnicos, parlamento e sociedade, para que, de fato, seja assegurada a orientação política da lei, por meio da alocação concreta de recursos e de instrumentalização legal complementar.

\section{EDUCAÇÃO DO CAMPO NA CONSTITUIÇÃO DE 1988}

Ao retratar o cenário social, desencadeado pela política educacional, Leite, S., (1999, p. 105) analisa o papel do Estado e a trajetória do ensino do campo, mostrando que os camponeses e suas demandas ficam, à margem do fazer institucional, já que alguns gestores municipais defendem a concepção que privilegia a hierarquia entre a cidade e o campo. Assim, "[...] o ponto crucial não está no planejamento em si, mas no ponto em que esse planejamento estabelece a intervenção do Estado no processo educativo, na implantação de uma política educacional em função dele próprio e não nos objetivos da sociedade".

A Constituição de 1988 inclui os princípios de responsabilidade do Estado e do direito de todos à educação, conferindo aos três níveis de ensino a mesma garantia. Embora não tenha estabelecido os espaços, subentende-se que seja instituída nos espaços rurais e urbanos como direito público subjetivo, concernentes a todas as modalidades de ensino e a todos os cidadãos. A ênfase para o âmbito técnico é a expressão maior da política educacional brasileira para o campo, desenvolvendo o Estado, a partir dos meados do século XX, uma formação embasada nos aportes fordistas, privilegiando a teoria do capital humano.Até a década de 1990, as mudanças foram muito tímidas nas Escolas Agrotécnicas Federais, no que diz respeito ao projeto político/pedagógico e, no âmbito de sua forma estrutural, permanece a forma de "Escolas Fazenda". 
A Lei 9.394/1996 em curso no país trará impactos, valendo citar que esta não parte do pressuposto básico de considerar como seus fins uma formação integral entre cultura geral e profissional, apesar de considerar que a formação profissional deve ser adequada à realidade do mercado de trabalho. Contudo, esta não é desvinculada das instâncias do sistema dominante que interligam as políticas sociais. Por vez do Movimento Nacional de educação do campo, a partir de iniciativas de professores, só na década de 2010, é que são construídos espaços de debates para modificar as organizações curriculares nas antigas escolas agrotécnicas, essas, transformadas nos campi dos IFETs - e, realizando também o ensino superior no campo -, a maioria dos cursos, na perspectiva agroecológica e limitada via editais, como Programas PRONERA, ESCOLA ATIVA e SABERES DA TERRA.

Partindo do pressuposto de que o ethos acadêmico é um substantivo relevante para a produção e ligação entre os saberes e os conhecimentos, não devendo ser desfigurado desde os anos iniciais da escolarização, é necessário mostrar os dados de sua permanência média, de apenas 03 e 04 anos, da população que reside no campo. Estes anos correspondem às categorias acesso e nível de instrução, constituindo um indicador central para mostrar a desigualdade social/educacional entre cidade e campo (REFERÊNCIAS, 2004).

\begin{tabular}{|c|c|c|}
\hline \multirow{2}{*}{ Regiões } & \multicolumn{2}{|c|}{ Anos de Estudo } \\
\cline { 2 - 3 } Geográficas & Urbano & Rural \\
\hline Brasil & 7,0 & 3,4 \\
\hline Norte & 6,4 & 3,3 \\
\hline Nordeste & 5,8 & 2,6 \\
\hline Sudeste & 7,5 & 4,1 \\
\hline Sul & 7,3 & 4,6 \\
\hline Centro-Oeste & 7,0 & 4,1 \\
\hline
\end{tabular}

Tabela 1- Número médio de anos de estudos da população de 15 anos ou mais Brasil e Regiões, 2001 Fonte: IBGE - PNAD 2001 apud Referências (2004, p. 13) ii $^{\mathrm{ii}}$.

Osdados apresentados pelo IBGE, em 2001, (REFERÊNCIAS, 2004, p. 13) apontam que o analfabetismo no Brasil é muito elevado, com uma taxa de 10,3\%, aprofundada no espaço rural. Neste, o Censo Demográfico aponta que 29,8\% da população, acima de quinze anos, são de analfabetos, sem considerar o índice de analfabetos funcionais, aqueles que com escolarização inferior às quatro séries do ensino fundamental. Este problema não é o único, cita-se o da exclusão de crianças de 07 aos 14 anos da escola, com cerca de 2,7 milhões (1996), com percentual mais expressivo nas periferias das cidades e no campo, conforme tabela:

\begin{tabular}{|l|l|l|l|l|l|l|}
\hline \multirow{2}{*}{$\begin{array}{c}\text { Regiões } \\
\text { Geográficas }\end{array}$} & \multicolumn{9}{|c|}{ Taxa de Analfabetismo(\%) } \\
\cline { 2 - 7 } & \multicolumn{2}{|c|}{ Total } & \multicolumn{2}{c|}{ Rural } & \multicolumn{2}{c|}{ Urbana } \\
\cline { 2 - 7 } & $\mathbf{1 9 9 1}$ & $\mathbf{2 0 0 0}$ & $\mathbf{1 9 9 1}$ & $\mathbf{2 0 0 0}$ & $\mathbf{1 9 9 1}$ & $\mathbf{2 0 0 0}$ \\
\hline Brasil & 19,7 & 13,6 & 40,1 & 29,8 & 13.8 & 10,3 \\
\hline Norte & 24,3 & 16,3 & 38,2 & 29,9 & 15,5 & 11,2 \\
\hline Nordeste & 37,1 & 26,2 & 56,4 & 42,7 & 25,8 & 19,5 \\
\hline Sudeste & 11,9 & 8,1 & 28,8 & 19,3 & 9,8 & 7,0 \\
\hline Sul & 11,9 & 7,7 & 18,2 & 12,5 & 9,7 & 6,5 \\
\hline Centro-Oeste & 16,6 & 10,8 & 30,0 & 19,9 & 13,6 & 9,4 \\
\hline
\end{tabular}

Fonte: IBGE - Censo Demográfico 1991 e 2000 apud Referências, 2004, p. 14.

Tabela 02 Taxa de analfabetismo da população de 15 anos ou mais do Brasil em Grandes Regiões 1991-2000 
Em relação ao ensino médio, o problema é mais acentuado, pois a sua ausência, quase no total, existindo apenas algumas experiências e as Escolas Agrotécnicas, relegadas ao abandono (REFERÊNCIAS, 2004). Nesse sentido, diz bem Arroyo, "[...] que o forte dessa perspectiva é propor a adaptação de um modelo único de educação aos que se encontram fora do lugar, como se não existisse um movimento social, cultural e identitário que afirma o direito a terra, ao trabalho, à dignidade, à cultura, e à educação (SOARES, E., 2002, p. 76).

Assim, como assinala Soares (2002), percebe-se que, no texto das Constituições brasileiras, as abordagens referentes ao ensino no campo se expressam descontextualizadas e voltadas aos interesses das elites, seja para atender à ordem social, seja para direcioná-la à formação para o trabalho - este tratado como espaço privado - e aos valores do mercado, ou para atender a ambos simultaneamente. A importância política da educação do campo, tanto em sua especificidade, como em sua qualidade social, só foi discutida quando os movimentos sociais passaram a construir e exigir outra educação, interferindo e exigindo políticas públicas para os filhos dos trabalhadores. Decorrentes dessas ações, iniciativas vão ser constituídas na dimensão social, de programas e projetos consistentes," mas sob forma de editais.

\section{A EDUCAÇÃO NA LDB DE 1996: ADEQUAÇÕES AO CAMPO}

Considerando a legislação como uma das fontes documentais para compreender as políticas educacionais, a Lei de Diretrizes e Bases da Educação (LDB), nº 9394/96, apesar de suas contradições sociais, é um instrumento fundamental para analisar o último período decenal do século XX.Momento este de disputa entre empresários e setores organizados da sociedade civil pelo campo educacional. Esta Lei retrata, até certo ponto, uma compreensão da riqueza da diversidade cultural do campo, mediada pelos Artigos 207, 208 e 210 da Constituição de 1988, quando estabelece no seu Artigo 28:

I - conteúdos curriculares e metodologias apropriadas às reais necessidades e interesses dos alunos da zona rural;

II - organização escolar própria, incluindo a adequação do calendário escolar às fases do ciclo agrícola e às condições climáticas;

Ao substituir o processo de adaptação pelo de adequação para a educação nas escolas do campo, o texto da LDB considera as peculiariedades da vida nesse espaço, em relação ao trâmite e tratamento escolar, identificando e respeitando a sua diversidade cultural, social e geográfica. Este ponto de inferência de normatização pela Lei traz, indiretamente, referências biográficas de movimentos sociais do campo, inserido e defendido pelo legislador, que inaugura uma forma de inclusão de reivindicações históricas, em um documento oficial. Como mostra Soares (DIRETRIZES, 2003, p. 30), "o legislador inova", à proporção que considera algumas referências para uma educação popular, sem as feições de enquadramento, parecendo, assim, se transpor aos atores sociais.

Apesar de reconhecer as diversidades do campo, as fundamentações contidas no documento, esses legisladores, como assinala Soares (2002), não rompem com a racionalidade tecnocrática e mercantilista de um projeto de educação para o país, resultante da cultura política brasileira autoritária, acenando para a continuidade de uma política a ser desenvolvida em bases clientelistas, portanto, escassa de debates. Assim, não assegura outra política educacional. No texto oficial, por um lado, é reconhecida a heterogeneidade cultural do campo e a importância do respeito às diferenças, rompendo com a 
homogeneidade. Por outro, mantém o vínculo, de certa forma, hierárquico com o projeto geral de educação, pressupondo a necessidade de controle sobre a organização dos sistemas de ensino, por meio da coordenação centralizada em todas as dimensões educacionais pelo governo federal, sob o discurso de descentralização.

O texto da LDB, em decorrência do princípio de adequação, contém um aceno dirigido à abertura para a elaboração das Diretrizes. A sua elaboração e aprovação no CNE, ocorreram porque houve as ações dos movimentos sociais e de trabalhadores em educação, como correlação de forças para viabilizar realizações de seminários, como instâncias para debates democráticos, fazendo proposições que foram incorporadas às Diretrizes Operacionais.

Embora a LDB tenha reconhecido a diversidade regional e local, quanto a conteúdos e metodologias concernentes às demandas dos povos do campo, a lei por si só não garante a efetivação das condições necessárias preconizadas e condicionantes para o exercício prático de tais proposições. É notória a importância desses incisos e de sua valorização, de maneira geral e específica, para o desenvolvimento do processo educativo ser, na prática, à base das especificidades do campo, como mostra Soares, E., (2002). Evidencia-se, assim, a necessidade de realizar tal processo, procurando ultrapassar a herança da política micromacroreducacional, sob a lógica de celebração do mercado, pelos últimos governos.

A trajetória da descentralização aponta que esta foi decorrente de "[...] uma determinação legal imposta à escola", o que "[...] dificulta o engajamento dos atores educacionais e esvazia o debate político em torno da necessidade de conceber um projeto político/pedagógico articulado com as mudanças ocorridas na sociedade" (CABRAL NETO, 2004, p.27). O redimensionamento das políticas educacionais é uma perspectiva urgente dos movimentos sociais para assinalar mudanças no quadro geral do sistema educacional e na qualidade do ensino da escola pública, isto tão presente no discurso governamental, mas não viabilizada na prática. Pelo contrário, mantêm-se as condições precárias para a escola pública, como as destacadas pelos dados estatísticos do ensino fundamental, pois "[...] revelam que $59 \%$ das crianças de $4^{\text {a }}$ série ainda não estão alfabetizadas" ( CABRAL NETO, 2004, p. 23) ${ }^{1}$.

A base para a territorialização das demandas educativas da sociedade é a dos movimentos sociais. Logo, evocar tais demandas implica defender uma concepção que tenha aportes inclusivos, que não assente exclusividade ao geral, nem reduza o específico à forma complementar do ensino escolar (SOARES, E., 2002).

Entendendo o específico e sua inserção como meios de conteúdo e finalidades, de forma horizontal de prioridades, é necessário que faça parte da política para a educação, não sendo dissociada de uma formação de cultura geral e profissional. O problema está em discutir as formas de valorização que não se dão em si mesmas, mas sim situadas no contexto político.

Não basta introduzir, nas escolas do campo, os conteúdos regionais e locais e empreender narrativas na cultura. É necessário configurá-las no contexto político/pedagógico, com postura crítica do professor, o que implica desenvolver uma política de continuidade de formação e de carreira, para que o professor se atualize e esteja atento ao contexto histórico-social. Nesse sentido, considerar o que o sistema cria, transforma e mantém, as finalidades, conteúdos, princípios, diversidade e especificidade do campo têm relevância social para que se faça ultrapassar os dispositivos da Lei, de forma democrática e inclusiva para todos os atores, como assinala Soares, E., (2003, p. 31): “[...] ao combinar o artigo 26 e 28 , não se pode concluir apenas por ajustamento. Assim, parece 
recomendável, por causa da própria Lei, que a exigência mencionada no dispositivo pode ir além da reivindicação de acesso, inclusão e pertencimento".

A relevância social de saber qual é e o porquê do projeto de educação - o que está por trás da Lei -, é necessário, como um pressuposto norteador, para se ter o entendimento do movimento/funcionamento da política educacional, do que ela cria e transforma, além de se considerar as diferenças sociais que entram em jogo, considerando que a forma do trabalho educativo preenche funções sociais. Então, como mostra Soares, E., (2003), a política educacional é concebida em um espaço político de movimento, de articulações, no qual cabe reivindicar decisões que conduzam à pertinência democrática do que se pretende e muito além do que é preconizado inicialmente, sempre de acordo com as demandas sociais. Assim, pode-se incluir e afirmar tais demandas para as políticas públicas, rejeitando tendências que se propõem absolutas e conduzem à adaptação.

Reconhecer as demandas sociais significa respeitar os seus sujeitos, com direitos iguais, em uma sociedade desigual, que os concebe iguais, mas que os trata e os reduz a desiguais no exercício prático das leis e das relações sociais e econômicas, não considerando que todos os indivíduos são construtores da História, não estranhos, muito menos seus expectadores. Então, ao prever a organização escolar própria, com base em um calendário escolar que corresponda às diferentes fases das culturas agrícolas e à dimensão da natureza do trabalho do campo, a legislação em foco abrange um contexto especial das necessidades dos educandos do campo quanto ao acesso à educação escolar, o que não pressupõe reforçar a dicotomia entre a cidade e o campo, apenas, considerar as suas necessidades específicas.

\section{EDUCAÇÃO DO CAMPO NO PLANO NACIONAL DE EDUCAÇÃO}

O ideário do urbano como modelo de vida, de educação e como um projeto único a ser seguido, fez-se presente na trajetória histórica da legislação, seja nas Constituições, seja nas Leis de Diretrizes e Bases para a Educação Nacional. Como assinalam Arroyo (2001); Mançano Fernandez (2002) e Soares (2002), o campo foi concebido e tratado como espaço de atraso, como um espaço de ninguém, vazio, o qual deve ser ocupado, preenchido e civilizado, com algumas letras da cultura geral, pois, para os "fora do lugar", bastam estes fragmentos para que "possam desenvolver suas funções e serem integrados na sociedade".

O Projeto das elites para afirmar o campo, os seus projetos, têm um sentido exclusivode adaptação, envolvendo todas as políticas públicas. Nesta perspectiva, esta argumentação de adaptação total ou parcial abrange a política educacional, a escola, a sociedade, estendendo-se e prevalecendo nas propostas e debates pedagógicos, isto já registrado no $8^{\circ}$ Congresso Brasileiro de Educação, em 1942. Como assinala Souza, N. (2004, p. 185), “[...] a instrução deve se limitar aos conhecimentos que tenham aplicação prática na vida sertaneja". Prover um ensino de caráter adaptativo, implica priorizar o significado de controle maior pelos planejadores do Estado, para poderem realizar os ajustes políticos e econômicos, também por meio da escola.

Essa referência constitui a base para as propostas de adaptação ao ensino no campo, sendo mantida na trajetória das políticas até recentemente. Assinalando, desse modo, o prevalecer de ações sociais verticalizadas, conduzidas por técnicos que compreendem a identidade do campo como inferior, enquanto condutoras do projeto de seus sujeitos para o tempo pretérito. Esta não é tomada como um projeto dinâmico que tem referências culturais e identitárias movidas pela lógica de um tempo social diferente, lógica que combina e reproduz suas identificações com caráter próprio e transgeracional, mantendo técnicas e saberes entrelaçados entre a vida humana e a da natureza física. Uma identidade 
diferente da imposta pelo colonizador de ontem e pelo de hoje, que tem diversidade, com características de permanência e de transformação, pela própriadinamicidade do processo histórico, embora o capitalismo tenha trazido modificações nos hábitos, como no vestuário, nos gestos e na linguagem, o desejo de acesso às tecnologias que trazem melhorias na qualidade de vida e no consumo. Esta identidade, na leitura que se faz, é movida, também, pela lógica produtiva, que não se direciona, prioritariamente, para o mercado, mas sim visando à reprodução da unidade familiar; na maioria das experiências, pelas tecnologias não obsoletas, embasadas na diversidade, na ênfase do uso da força humana em interrelação com a biodiversidade.

Esse pensamento dos planejadores - que tenta uniformizar - está presente no Plano Nacional de Educação - PNE, aprovado no segundo governo do presidente Fernando Henrique Cardoso, de 1998-2002. Também é expressão de continuidade de políticas elaboradas já no Plano Decenal de Educação para Todos, a partir do governo do presidente Itamar Franco, 1992-94, refletindo os interesses das políticas internacionais. Também dá continuidade às referências do modelo citadino, com ênfase na estruturação do ensino em séries, apesar de prever a flexibilização da organização escolar, no âmbito de seus objetivos e metas. Essa preferência é notória, quando estabelece tal organização escolar seriada - como ponto essencial em sua diretriz, em seus objetivos e metas, prevendo "associar as classes isoladas unidocentes remanescentes a escolas de, pelo menos, quatro séries completas".

O "Plano Decenal de Educação para Todos", apresentado em 1992, para o período de 1993-2002, no Brasil, foi decorrente dessa lógica, conduzido pelo próprio MEC, com três eixos temáticos de metas, como a gestão e administração do sistema educacional, com ênfase na eficiência, produtividade, sistematização do processo;a universalização da educação básica, com a eqüidade, universalização, novas articulações institucionais; a formação da cidadania para o desenvolvimento, envolvendo o movimento para se deter as competências cognitivas e sociais, visando à participação na vida socioeconômica brasileira, novos padrões de conteúdos mínimos nacionais (MELO, 1998).

O Ministro da Educação, Murílio de Avellar Hingel, assumiu o cargo em setembro de 1992, no governo do presidente Itamar Franco, participando, na China, em 2003, como assinala Peroni (2003), da Conferência de Educação para Todos, constatando que o Brasil não havia cumprido as metas estabelecidas no acordo de Jomtien, de 1990. A opinião do Ministro, em seguir tais orientações políticas já acena sobre a concepção que norteia o planejamento, e para quem é a prioridade e a secundaridade da política do governo. Visualizando cumprir o acordo, o Ministro parte para a ação:

[...] o Brasil ainda não tinha tomado iniciativas consistentes para cumprir o compromisso da Declaração Mundial de Educação para Todos. [...] após ter convivido com esta experiência de indiferença de nosso país em torno de um compromisso assumido internacionalmente, tomei a decisão de elaborar o Plano Decenal de Educação para Todos, determinando que sua metodologia se orientasse por uma ampla participação e mobilização da sociedade (HINGEL apud PERRONI, 2003, p. 94). ${ }^{\text {iv }}$

O Plano Decenal, dessa forma, confere a meta de delinear perspectivas econômicas, em nome das sociais, à base de enfrentamento dos problemas e elaboração de estratégias para realizar a "[...] universalização da educação fundamental e a erradicação do analfabetismo, indicando as medidas como os instrumentos para a sua implementação" (SAVIANI, 2004, p. 77). Assim, portanto, por meio de realizações de eventos, promovidos 
pelo MEC, como "A Semana Nacional de Educação para Todos", em 1993, e a "Conferência de Educação Nacional de Educação para Todos", em 1994, ambos constituem um processo para reforçar os aportes teóricos/metodológicos para o Plano Decenal, culminando com a elaboração do Acordo Decenal de Educação para Todos. Tais eventos empreenderam a descentralização da política educacional, com o objetivo de transferir as responsabilidades para os âmbitos dos poderes estaduais e municipais. Este Acordo é um instrumento de referência para a afirmação das políticas educacionais neoliberais, uma vez que seus programas têm um caráter emergencial, enfatizando uma contenção no financiamento da educação.

O Plano corresponde, na concepção e elaboração, como medida de urgência para atender às exigências de organismos financeiros, visando à obtenção de financiamento internacional, notadamente, pelo Banco Mundial. Este, entretanto, insere a proposta dessas reformas para a educação no Brasil, tornando as suas referências as orientações norteadoras, visíveis estas quando restringem a política educacional à educação fundamental oficial, apenas, para crianças dos 07 aos 14 anos. Na prática, as ações do governo voltaram-se para a redução do financiamento, configurando um quadro de descaso com a formação escolar de qualidade.

É necessário buscar as condições para a realização da educação do campo, como uma das referências abertas no Plano Nacional de Educação, para que esta seja assegurada pela via do financiamento estatal e para que haja outras modalidades de organização de ensino que viabilizem possibilidades e compromissos de educadores, e também para que se faça cumprir os indicativos presentes em seu interior. $\mathrm{O}$ cumprimento pelo poder público, principalmente dos que acenam para a diversidade regional e atendem aos interesses das populações, estendendo-se para os Planos Estaduais e Municipais, assim como em outros projetos, como o político/pedagógico, com caráter democrático e concernentes à educação no espaço público.

O documento das Referências (2004, p. 30) registra as condições precárias para a efetivação desse direito social, assegurado na própria legislação que,

[...] no caso do ensino fundamental de $1^{\mathrm{a}}$ a $4^{\mathrm{a}}$ série, das 1.146 .451 crianças atendidas, somente a metade é transportada para as escolas na zona rural. Este percentual aumenta no caso das séries finais do ensino fundamental. Dos 1.814.715 alunos residentes na zona rural e que são atendidos pelo transporte escolar público, 69\% têm como destino uma escola urbana, sugerindo a carência de escolas rurais que oferecem esse tipo de ensino. O mais grave desse processo é que, como mostram estudos da área, os alunos da zona rural, ao continuarem seus estudos numa escola urbana, passam por uma dura vivência de preconceito, que muitas vezes os leva ao abandono escolar.

Além de os recursos financeiros terem sido insuficientes, a disponibilidade para sua aplicação não foi, em geral, efetivada nas escolas da cidade, muito menos nas do campo.

O projeto da sociedade brasileira foi embasado em aportes políticos e econômicos que privilegiaram a concentração de renda, principalmente, em meados do século XX, encaminhando para um aprofundamento entre as classes trabalhadoras e proprietárias. Entre 1964 e 1985, os governos militares exerceram uma política austera para reimplementar o crescimento econômico; a partir de 1985 até 2010, o cenário das políticas é constituído porgovernos que acenam às propostas neoliberais, enfatizando o mercado como referência para a organização social, política e econômica do país. Esta abertura para a configuração das políticas, mediadas pelo mercado, é caracterizada pela " [...] cisão entre 
o social e a sociedade, essa subordinação da vida social à econômica cresce no discurso. Hoje está mais forte, até do que no regime militar [...]. A privatização das empresas estatais [...] para o resgate da dívida social" (RIBEIRO, J. 2000, p. 24). O período pósprivatizações continuou com a característica de retração às políticas sociais, implicando, como mostra o autor, em aumento dos déficits sociais, e que o problema antecede a este recurso, uma vez que os meios de comunicação foram os mediadores do discurso dominante para a privatização da- sociedade.

Como afirma Ribeiro, J. (2000, p.19), a voz dos atores dos poderes econômico e político, do governo e da imprensa conduz ao entendimento de que "a 'sociedade' veio designar o conjunto dos que detêm o poder econômico, ao passo que o 'social' remete [...] a uma política para minorar a miséria. A - sociedade - é ativa: ela manda [...] sabe o que quer". Dessa forma, o social, na concepção da classe dominante, - é uma dimensão secundária -, por isso, conduzido por políticas focalizadas "[...] na esfera do paliativo [...]" (RIBEIRO, J., 2000, p. 20). Destaca-se, nesta reflexão, o tratamento diferenciado conferido às áreas do social, como se fossem apêndices da sociedade, com isto aprofundando as desigualdades sociais.

O movimento de gestão dos governos - dos presidentes José Sarney, Fernando Collor de Melo, Fernando Henrique Cardoso, acrescente-se, do presidente Luís Inácio Lula da Silva, no modo de construir/ajustar as políticas públicas da dimensão social, como se essas fossem mero instrumento quantitativo (REIS, 2006).

\section{DIRETRIZES OPERACIONAIS, ENTRE AVANÇOS E DESAFIOS AO CAMPO}

A educação básica nas escolas do campo é compreendida como parte constitutiva da educação nacional, defendendo-se que esta é vinculada, não isolada, nem exclusiva, de modo a incluir diversidades culturais, étnicas, saberes locais, nas formas, teórica e prática, necessitando ser compreendida na organização e relação com a vida social, e na interrelação, com a cidade e demais territórios.

A luta por outra educação do campo contribuiu para a construção do referencial das Diretrizes. Estas, não estão dissociadas da questão e tensão do desenvolvimento regional.Este compreendido, na perspectiva da sustentabilidade, sob a lógica contrahegemônica que concebe a territorialidade para ser cuidada, interdependente ao desenvolvimento social; esta defende uma economia política não em si mesma, não referenciada pelos aportes do mercado e da acumulação econômica.Concebe essa luta do Movimento Nacional por uma Educação do campo,que a organização curricular escolar deve estar inserida no campo de estudos do meio ambiente, de modo a problematizar essas políticas de desenvolvimento, pontuando a complexidade das diversas relações sociais inerentes a essa temática. Por isso, defende tal movimento, que tal temática, ao ser estuda na escola do campo, contribui para que haja apreensão de processos de uso e ocupação territorial, na perspectiva de estimular reflexões e planos/práticas de uso racional dos meios de subsistência naturais, interligados com a preservação da biodiversidade; uma vez que se concebe que as tecnologias de produção não são aportes acima dos recursos biológicos, mas sim, elementos interdependentes para dar continuidade à manutenção da vida. Este processo se dá com tecnologias em bases ecológicas, considerando a ciência, a tecnologia e a educação, construídas sob uma pluralidade associada às culturas e às civilizações (SHIVA, 2003, p. 162; REIS, 2006).

Assim, essas desqualificam sua capacidade para a apreensão do conhecimento acumulado historicamente e de sua apropriação e produção de novos, evitando e até mesmo negando que a escola do campo seja aporte de formação para além da cidadania 
burguesa, para a identidade, para o trabalho e para a cultura. Um exemplo é o atual Plano Nacional de Educação, aprovado em 09 de janeiro de 2001, proposto pelo MEC, que não oferece proposições específicas com qualidade social destinada a uma educação integral para os filhos dos trabalhadores do campo, apesar de contemplar problemáticas gerais. Outro exemplo são os Parâmetros Curriculares Nacionais que não incluem a escola do campo como construtora do conhecimento; pelo contrário, os seus aportes pedagógicos são embasados em um currículo voltado para a cidade. Embora apresentando o campo como incluso, valorizam, apenas no discurso, a sua diversidade cultural.

O dimensionamento entre a educação do campo, o trabalho e o desenvolvimento sustentável, entre a cidade e o campo, é defendido por outra concepção de desenvolvimento e de educação, a qual entende a importância da História para a compreensão da sociedade e concebe a interdependência entre as diversas dimensões da realidade: econômica, política, social, ecológica e cultural. Esta concepção não defende uma pseudo-inclusão, mas sim, uma inter-relação entre trabalhadores do campo, floresta, rios e os da cidade, considerando que existem interesses diferentes e opostos entre esses e os latifundiários, detentores de outro projeto para o campo.

Esses trabalhadores reivindicam inclusão social, compreendendo que esta se dá "[...] como situação social de pertencimento e de identidade comum" (MARTINS, 1997, p.17). Desse modo, uma inclusão que garanta a condição de políticas educacionais no espaço público, com caráter universal, contribuindo para a reprodução digna da vida humana e a de seus meios de existência em conexão com a natureza.

Neste processo reivindicatório/propositivo por outra política educacional, tais atores sociais vão além da luta pela educação básica, expressando a demanda que ultrapassa a esfera deste grau de ensino - um limite das Diretrizes Operacionais. A demanda concerne da educação infantil ao ensino superior e da relação interativa da escola, nas dimensões orgânicas da realidade, expressando a importância de se considerar que os projetos não são neutros. Assim, é pertinente a vigilância sobre qual a educação e qual o inter-relacionamento entre campo e cidade que o poder público está defendendo e realizando.

A continuidade e a valorização dos saberes locais são categorias socialmente relevantes para resguardar seu potencial, e a escola é o espaço para prover outra educação, com qualidade social, considerando a importância da formação integral para a constituição da concepção de mundo do jovem e deste poder fazer a ultrapassagem de indivíduo em si para o indivíduo para si, como assinala Duarte (2003), embasando-se em Vigotsky e Marx:

Nessa concepção vigotskiana do desenvolvimento da personalidade por meio do conhecimento mais profundo da realidade objetiva (inclú́das nesta as ações realizadas pelos seres humanos e pelo próprio indivíduo em desenvolvimento) evidencia-se a importância da educação escolar, da transmissão do saber objetivo pelo trabalho educativo na escola. Ao conseguir que o indivíduo se aproprie desse saber, convertendo-o em 'órgão de sua individualidade', o trabalho educativo possibilitará ao indivíduo ir além dos conceitos cotidianos, superá-los, os quais serão incorporados pelos conceitos científicos. Dessa forma, o indivíduo poderá conhecer de forma mais concreta, pela mediação das abstrações, a realidade da qual ele é parte (DUARTE, 2003, p. 82).

Um trabalho educativo, que se propõe ser instrumento para o indivíduo conhecer a realidade, necessita incluir os saberes locais, para não se esvaírem pelo esquecimento imposto - através de mecanismos sociais e ideológicos neoliberais que priorizam o 
presenteísmo fora do contexto histórico (HOBSBAWM, 1998, p. 22). De acordo com Germano (2001, p. 230): “[...] o neoliberalismo, [...] pode ser definido como um 'sistema de receitas práticas para a gestão pública', cujas palavras chaves são, agilidade, eficiência, eficácia, produtividade, nada, portanto, que diga respeito aos ideais de eqüidade e justiça".Contrapor-se a este movimento, que infere a lógica econômica, é uma proposição urgente e necessária, socialmente, para que se tenha outra política pública em que a escola possa fazer a transmissão e a construção do conhecimento.

Nos governos dos presidentes Fernando Henrique Cardoso e Luís Inácio Lula da Silva -, apesar de todo o discurso oficial e propaganda veiculada em torno do slogan "Educação para Todos", em geral, o incentivo da política educacional foi voltado, essencialmente, para o setor produtivo, conferindo uma política focalizada, como o FUNDEF, só em nível fundamental. A partir de 2007, a criação do FUNDEB, abrange o Nível Médio, mas ainda insuficiente. As ações, por meio de programas pontuais, em sua maioria, são restritas, não atendem às demandas históricas da sociedade - necessidades específicas, quantitativa e qualitativamente, entre campo, floresta e cidade; assim, tais ações são tímidas para estender e afirmar um conhecimento escolar contextualizado entre cultura geral e profissional.

Os dados sobre o cenário das escolas do campo no Brasil, a partir de uma pesquisa realizada pelo Instituto Nacional de Estudos e Pesquisas Educacionais Anísio Teixeira (INEP), nas áreas de assentamentos, podem ser lidos como indicativos de uma condição desfavorável à formação integral, inadequada para o jovem ter uma compreensão contextualizada da realidade, bem como para atender às necessidades dos povos da cidade, do campo e da floresta, sob bases para inserir no sistema escolar e ligar os conhecimentos dos pais, avós e os da ciência. Conforme demonstrativo abaixo:

\begin{tabular}{|l|c|c|c|c|c|c|}
\hline \multirow{2}{*}{ DESCRIÇÃO } & \multirow{2}{*}{ GERAL } & \multicolumn{5}{|c|}{ REGIÃO } \\
\cline { 3 - 7 } & & NORTE & NORDESTE & CENTROOESTE & SUL & SULDESTE \\
\hline Totalmente ajustado & 4,2 & 4,0 & 3,8 & 3,4 & 7,4 & 6,5 \\
\hline Parcialmente ajustado & 10,2 & 11,4 & 10,0 & 9,1 & 7,1 & 13,1 \\
\hline Não ajustado & 85,6 & 84,6 & 86,3 & 87,5 & 85,5 & 80,4 \\
\hline
\end{tabular}

\footnotetext{
Quadro 4 - Calendário Escolar Ajustado ao Período das Safras (\%) - Brasil e Grandes Regiões 2004
}

Fonte: MEC/INEP e MDA/INCRA/PRONERA - PNERA apud Referências 2004.

Os dados quantitativos possibilitam uma amostragem panorâmica do que acontece em termos qualitativos acerca da política educacional para as escolas do campo. As estatísticas sobre o calendário escolar, aparentemente, compartimentado dos outros fatores que constituem o currículo escolar, no entendimento que se faz, representam um elemento norteador para se exigir outra política educacional. O percentual de $85 \%$ corresponde um dado, praticamente, hegemônico, sobre a adaptação do sistema de ensino das escolas brasileiras, tendo em vista que, sobre a categoria calendário não se considera as especificidades concernentes às necessidades socioeconômicas das famílias trabalhadoras, as quais têm nos adolescentes uma força de trabalho significativa, dependendo estas unidades produtivas desta força de trabalho - marginal -. É uma adaptação hegemônica, uma vez que não se faz, pelo menos, os ajustes dos calendários escolares com os períodos especiais do processo de trabalho na agricultura, por regiões e localidades, conforme já indica a leitura sobre o que está por trás dos números dos quadros estatísticos.

\section{REGIÃO}




\begin{tabular}{|c|c|c|c|c|c|c|}
\hline$\underline{\text { DESCRIMINAC̄̃ }}$ & $\underline{\text { GERAL }}$ & $\underline{\text { NORTE }}$ & $\underline{\text { NORDESTE }}$ & $\underline{\underline{\text { CENTRO }}}$ & $\underline{\text { SULSTE }}$ & $\underline{\text { SUDESTE }}$ \\
\hline $\begin{array}{c}\text { Escola turmas } \\
\text { multisseriadas }\end{array}$ & $\underline{70,5}$ & $\underline{84,9}$ & $\underline{68,2}$ & $\underline{60,5}$ & $\underline{45,6}$ & $\underline{57,2}$ \\
\hline$\underline{\text { Com 1 turma }}$ & $\underline{52,0}$ & $\underline{59,7}$ & $\underline{46,6}$ & $\underline{52,9}$ & $\underline{41,9}$ & $\underline{50,5}$ \\
\hline$\underline{\text { Com 2 turmas }}$ & $\underline{36,3}$ & $\underline{30,1}$ & $\underline{42,0}$ & $\underline{28,4}$ & $\underline{38,9}$ & $\underline{42,5}$ \\
\hline Com 3 ou + turmas & $\underline{11,4}$ & $\underline{9,9}$ & $\underline{11,0}$ & $\underline{18,0}$ & $\underline{19,2}$ & $\underline{6,5}$ \\
\hline
\end{tabular}

Quadro 5 - Existência de Turmas Multisseriadas no Ensino Fundamental (\%) Brasil e Grandes Regiões - 2004

Fonte: MEC / INEP e MDA / INCRA / PRONERA - PNERA

Para a reversão de tal política, o Encontro Nacional de Educadores e Educadoras da Reforma Agrária (ENERA), realizado em 1997, é uma referência para a História da Educação brasileira, visto que foi a instância para os debates sobre a política educacional em curso, sob orientação de pressupostos democráticos. As referências para este debate em torno da escola do campo constituem um conjunto de elementos embasados nas demandas trazidas pelos Movimentos Sociais. Estas, em sua maioria, se vinculam às experiências educativas escolares, como as do MST, a partir de 1984.

Conseqüentemente, a discussão referente à identidade do campo e à sua afirmação, como parte constitutiva da realidade brasileira, sem referências verticais entre cidade e campo, foi abraçada pelas universidades públicas. Um posicionamento destas, no sentido não só de compreensão, como também de vinculação, para atender às demandas dos trabalhadores do campo, em função da nova configuração deste, por meio da luta política dos movimentos sociais. Estes movimentos mostram a importância de se compreender a inter-relação entre as diversas políticas públicas e do Estado em relação a estas.

As Diretrizes Operacionais para a Educação Básica nas Escolas do Campo foram aprovadas pela resolução $n^{0} 1$, de 3 de abril de 2002, da Câmara de Educação Básica do Conselho Nacional de Educação CEB/CNE, sendo um marco referencial das políticas públicas, enquanto instrumento norteador para a constituição, a implementação, a operacionalização e a avaliação de programas e projetos educativos para o campo.

A aprovação destas Diretrizes representa, como assinala Fernandez (2002), um ponto relevante que demarca uma conquista, decorrente da luta histórica dos movimentos sociais, que, paradoxalmente, exige, por meio do movimento histórico, um ponto de continuidade. Esta se dá, mediante novo ponto de partida, com a participação dos trabalhadores, em torno da organização social.

Esta organização pressupõe a necessidade de se estar atento às diversas políticas públicas e às condicionalidades estruturadas para tais políticas, inserindo-se, nesse contexto, as formas de seu desenvolvimento, para o campo, a política agrária, a agrícola, a ambiental e a tecnológica, com desdobramentos para os educandos. O sentido de interrelação horizontal entre campo e cidade constitui a base principal de reivindicação dos setores organizados para garantir as políticas públicas, em instâncias coletivas democráticas. Como expressa Fernandez (2002, p. 91):a aprovação das Diretrizes [...] é um novo passo de uma caminhada de quem acredita que o campo e a cidade se complementam e, por isso mesmo, não podem ser pensados como relação de dependência eterna ou pela visão urbanóide e totalitária que prevê a intensificação da urbanização como o modelo de país moderno. [...] um país moderno, é aquele que tem um campo de vida, onde os povos do campo constroem sua existência.

A força do parecer das Diretrizes é significativa, pois este apresenta como princípio, a defesa de políticas sociais universalistas, rejeitando as de caráter compensatório. Assim, estas remetem à participação qualificada dos professores, alunos, 
pais, movimentos sociais e setores organizacionais, visando à vinculação da escola às demandas do campo, pois,

Retomando a discussão sobre como a educação do campo deve ser tratada, portanto, em inter-relacionamento dinâmico e complementar com a cidade, não como algo estranho e, muito menos, como algo atrasado, o Movimento de Articulação Nacional por uma Educação do Campo evidencia a importância de que a política educacional seja voltada para a sua dimensão. Para isto, a escola é uma referência para a apreensão do conhecimento, para o exercício da reflexão contínua dos educadores sobre a educação e as suas responsabilidades no conjunto da sociedade, em torno de fazer diferente, como o de se estar atento aos próprios sistemas de ensino, enquanto parte desta sociedade e do sistema dominante, em cuja reflexão os contextos social e político estejam presentes, visando evitar as reformas/mudanças para desqualificar a força de trabalho e a formação do ser humano.

Visando que esta perspectiva possa ser levada a cabo, caminhos tensos foram percorridos para a conquista da educação do campo no espaço oficial do MEC. As Diretrizes são corolário desse movimento no campo. Constituem-se na forma de dezesseis Artigos, vinculados entre si, tendo como eixo principal a importância dada à construção/reconstrução da educação do campo, expressando-se em um documento normativo, que inseredemandas sociais. Também configuram um caráter democrático, tendo em vista que há abertura, em instâncias deliberativas, como a criação de Fóruns de Educação do Campo, como no Pará, em 2004, o Fórum Nacional de Educação do Campo, em 2010 e Grupos de Trabalho em outros Estados, para a participação e para o debate em torno de sua implementação nos Estados e Municípios. O ponto de partida, nesta fase, foi o de divulgação das Diretrizes, por meio da realização de 24 Seminários Estaduais de Educação do Campo (MEC/SECAD/CEC, 2005), mas, até 2011 falta muito a se fazer nos Estados, para que demandas pontuadas na lei se tornem ações políticas. ${ }^{.}$

As Diretrizes constituem um avanço no interior de um processo que exige um compromisso de fazer presente encaminhamentos, com envolvimento permanente para a efetivação prática de pressupostos de uma pedagogia histórico-crítica, encaminhamentos já clamados na ENERA, em 1997, e na I Conferência Nacional por uma Educação Básica do Campo (1998), a qual "[...] teve como principal mérito recolocar, sob outras bases, o rural e a educação que a ele se vincula" (SOARES, E., 2002, p.63).

De acordo com o Artigo 5, em seu parágrafo único: “[...] as propostas pedagógicas das escolas do campo elaboradas no âmbito da autonomia dessas instituições serão desenvolvidas e avaliadas sob a orientação das diretrizes Curriculares Nacionais para a Educação Básica e a Educação Profissional de Nível Técnico" (DIRETRIZES, p. 42-43). As diretrizes consideram a escola do campo, e por considerar, dão visibilidade à questão da autonomia destas, expressando a importância de se reconhecer e dar ênfase ao lugar social das especificidades de cada escola. Neste sentido, assegurar a inserção do contexto social do campo na formação escolar é uma proposição de compromisso das Diretrizes para que o poder público educacional assuma de fato. Contexto social que poderá, por meio de lutas históricas de seus sujeitos, subsidiar parâmetros para a autonomia da (e para a) escola, mesmo considerando a impossibilidade desta autonomia com plenitude perante o sistema. Evitando assim, como assinalam Rosar e Krawczyk (2001, p. 39), o estado de subordinação às finalidades do projeto de sociedade capitalista e a "fetichização" da necessidade do conhecimento instrumental para inserção dos países ditos emergentes no mercado mundial.

Ao prever a abrangência da contemplação das dimensões da realidade social, em espaços da União, dos Estados e dos Municípios para os projetos político-pedagógicos das escolas, as diretrizes, mesmo respeitando a autonomia destas, fazem referência à 
vinculação com as orientações estatuídas na legislação nacional, por meio de observâncias, quer no processo de exercício prático, quer no processo de avaliação destas, mediante recomendação de ser objeto das orientações constituídas nas Diretrizes Curriculares Nacionais. De um lado, é significativo, posto a responsabilidade social que o Estado deve deter, se assumir uma Política Educacional Nacional inclusiva, extensiva a todas as vilas rurais; a fim de conceber e garantir responsabilidades políticas, sociais, de financiamento, respeitando as demandas dos trabalhadores do campo, não as demandas do latifúndio e as das empresas agropecuárias.

Por outro, esta política se for desenvolvida sob os preceitos atuais neoliberais, expressando-se "tecnicamente" via MEC, pode desrespeitar a própria legislação e, constituir-se-á compensatória, à medida que a ação é permeada pelo propósito de redução de encargos financeiros públicos, pela transferência aos Estados, Municípios, escolas privadas, ONGS , restando à União apenas, a continuidade de controle, apoio técnico e, reduzidamente, investimento suplementar (SAVIANI, 2004, p. 82). Neste sentido, qualquer ação dissonante do universo das Diretrizes Operacionais para a Educação Básica nas Escolas do Campo pode conduzir à desfiguração destas, tornando-as focalizadas.

\section{EDUCAÇÃO DO CAMPO NA LEGISLAÇÃO DE 2010: o decreto 7.352}

A luta pela educação do campo e de suas políticas é motivada pelo pensamento e ações de segmentos sociais da sociedade civil organizada, como o MST, referência histórica entre os movimentos sociais do Brasil contemporâneo do século XX e XXI. Sua caminhada situa-se em meio a embates com setores e movimentos hegemônicos que o caracterizam como grupo que procede às ações de criminalização. Nesse movimento relacional, este tem apoio de outros movimentos contra-hegemônicos, como o de professores, setores da Igreja Católica, Universidades e Sindicatos de trabalhadores, no sentido de evidenciar fundamentos para sua descriminalização.

Nos processos sociais vivenciados destaca-se a continuidade do MST, do Movimento Nacional e Movimentos Estaduais pela Educação do Campo, que têm, ao decorrer dos anos dessa primeira década de 2010, pontuado, eventos, audiências, agendas públicas e outras tipologais de ações, que reivindicam direitos sociais, como políticas públicas e condições concretas de acesso e permanência à terra, reforma agrária, à educação integrada, formações e qualificações de professores de escolas do campo, para além de Programas e Projetos da União.

Face a esse contexto estrutural, conjuntural e relacional de déficits com populações do campo, da floresta e águas, como indigenas, negros, ribeirinhos, seringueiros, quilombolas, os movimentos sociais que se organizam, para reivindicações e apresentação de propostas expressam as diversidades e problemáticas educacionais como também, as culturais, tecnológicas, de modo a exigir dos governos planos que sejam operacionalizados, para se ter o acesso e a permanência na educação escolar.

Compreender esssa luta e reivindicá-la como legítima é conceber que o processo se dá nos campos cultural e ideológico, para consignar transformações e superações na organização da sociedade. Assim compreender as partes constitutivas da realidade, não isoladamente, mas sim em inter-relação, para, poder compreender e expor conhecimento e ação mais próximos da realidade social. Isto exige perceber que o movimento é na direção de se ter uma síntese do processo social, como um resultado do concreto pensado, observando suas tensões, articulações e contradições, e não no pensamento fragmentado, o real isolado, como se este fosse produto do pensamento. Como evidencia Marx (1999, 
p. 28). Assim, é imperativo apreender o movimento dos processos legislacionais e suas inter-relações.

Processos esses, vinculados às demandas populares, que não nascem a partir de idéias/ações da maiorias dos gestores, como os do MEC, mas sim são conduzidos, pontuados pelos atores dos movimentos sociais. O Movimento Nacional por uma Educação do Campo, constituído, de Fóruns Estaduais e Comitês, como o Fórum Paraense de Educação do Campo - FPEC, e, a partir de 16 de agosto de 2010, do Fórum Nacional de Educação do Campo -FONEC, via este último, elaborou o ante-projeto que foi base para elaboração do Decreto que trata de Política Educacional do Campo.

O posicionamento político do FONEC, já no seu nascimento, expressa pontos e contrapontos do planejamento e operacionalidade de políticas educacionais do MEC/SECAD, evidenciando que há distância entre o que se propõe e o exercício prático; contexto e intertexto revelado pela materialidade única de Política de Estado, a Resolução CNE/CEB no 01/ de 03 de abril de 2002. Pós essa legislação, mesmo considerando, esforços da SECAD, ao desenvolvimento de Programas como o PRONERA, Projovem SABERES DA TERRA e o PROCAMPO (Formação de Professores), esses tiveram descontinuidades e tem limites geo-políticos, uma vez que são circunstanciados em esferas institucionais com cultura política conservadora; estendo-se essa para gestores estaduais e municipais. Tais programas são fundamentais para que a educação seja conduzida em regiões/espaços que antes, e sem esses, não tinham nada. No contexto das Políticas Educacionais, certamente o governo é indutor de cerca de 95\% dos programas em educação, em praticamente todos os Estados brasileiros.

É nesse movimento desestruturante, de exclusão includente que se movem projetos/programas, como o PRONERA, nos caminhos de uma inclusão excludente (SAVIANI, 2008), neo-tecnicista. Esse como contra-hegemônico a estrutura brasileira moderna e conservadora, na medida que se aproxima de uma concepção de educação que visa "[...] produzir, direta e intencionalmente, em cada indíviduo em singular, a humanidade que é produzida histórica e coletivamente pelos conjunto dos homens [...]" (idem, p. 422). Após 09 anos é que, pela ação de movimentos sociais que compõem o FONEC, como assinala (MUNARIM, 2011), o MEC regulamenta uma política estruturante de educação do campo. È de afirmar que este Decreto tem aportes que pode ir além do que estatui, mas uma lei não se faz em si mesma, exige um movimento de continuidade, de construção/aprimoramento de planos e ações de longo prazo, dialagodas com a sociedade, para se efetivar o sentido que o norteia; nessa direção cabe fazer a catarse, para transformação de conjunto.

É nesse intenção de construir aportes para outra política educacional, a partir, passando e de modo a chegar à prática social que o FONEC se move por enfrentar obstáculos de uma educação que se viabiliza para a produtividade na educação, que conduz duplamente à exclusão do jovem do campo. Nesse percurso de descaso do Estado e de uma prática de política educacional de governo, no final do governo Luis Inácio Lula da Silva, se expressauma legislação que é esforço de continuidade da luta de sujeitos do campo. No contexto de a sociedade civil pontuar suas demandas, é que foi efetivado o Decreto $n^{\circ} 7.352$, de 04 de novembro de 2010, o qual dispõe sobre a política de educação do campo e o Programa Nacional de Educação na Reforma Agrária -PRONERA. De modo que no seu

Art. 1o A política de educação do campo destina-se à ampliação e qualificação da oferta de educação básica e superior às populações do campo, e será desenvolvida pela União em regime de colaboração com os Estados, o Distrito Federal e os Municípios, de acordo com as 
diretrizes e metas estabelecidas no Plano Nacional de Educação e o disposto neste Decreto.

$\S 30$ As escolas do campo e as turmas anexas deverão elaborar seu projeto político pedagógico, na forma estabelecida pelo Conselho Nacional de Educação.

O Decreto evidencia, uma proximidade com necessidades das populações do campo, principalmente, ao expressar o alcance da oferta da educação básica e superior, essas vinculadas, às exigências de uma educação com qualidade social, o que implica garantir também a permanência desses sujeitos no tempo educativo escolar. Esse campo é o do financiamento ao longo do percurso da formação, no sentido de os fundamentos da política educacional serem rigorosos na fidelidade do cumprimento da obrigatoriedade do Estado, o que compreende uma cultura política institucional para além das políticas dos editais. É importnate ressaltar que apesar desse Decreto, é necessário estar atento para o horizonte longo que se tem na construção de políticas, que não se finda na lei, pelo que esta assegura, mas como esta se materializa, para além de diretrizes em si mesmas; exigese que os movimentos sociais estejam acompanhando ao a priori e posteriori. O por quê desta lei e de sua execução? Qual legado? Para quem?

A educação superior é referência constituinte na formação do educador, e, necessita ser estentida, de forma contínua, aos educadores do campo, rios e floresta, por essas demandas hsitóricas, a garantia de acesso a esse nível, corresponde a aproximação de possibilidades concretas na legislação. Na inter-relação MEC e IFEs compreende-se que essas últimas instituições passam a deter instrumento oficial para o fomento de uma cultura política que implemente e estabilize a formação docente e de outros profissionais. Essa conquista ao ES é potencializadora de gerar receitas, de modo a não esquecer, como registra Munarim (2011), que deve ser orientada a permanência da responsabilidade do Estado, camo é estabelecida na resolução de $\mathrm{n}^{\circ}$ 01, de 03 de abril de 2002, em garantir a qualidade em todos os níveis de ensino; nesse conjunto, a Educação Básica é a base para o acesso e sucesso da Educação Superior. Tal compromisso é fundamental, face a uma sociedade capitalista que detem a política social como antídoto para compensar a política econômica, esta anti-social (SAVIANI, 2007).

Nesse processo também se insere os itens de garantia de produção do material escolar, inclusão da diversidade cultural e tecnológica nos contextos de transmissão e construção do conhecimento escolar; conhecimento que deve estar ancorado no conhecimento social acumulado historicamente.

O projeto Político Pedagógico só o é plenamente se estiver vinculado ao movimento do real dos fenômenos histórico-educativos, assim, dialeticamente, exige que esse conhecimento esteja organicamente ligado ao conhecer como processo pedagógico fundante no ato educativo. Nessa compreensão, significa que a educação é prática social e seu desenvolvimento, na escola, ocorre como ato embasado na relação apropriação e criação do conhecimento, como processo permanente, como campo da formação humana, em sentido amplo. Assim emerge, qualificando princípios educativos, que primam por localizar e compreender aspectos de mudanças; processo que compreende usar a razão, como objeto de apreender a realidade, na medida que o conhecimento é inerente ao conhecer algo, internalizá-lo pela consciência, numa perspectiva de que a relação escola e seus conhecimentos seja de apropriação do real e não de produzir o conhecimento em si mesmo (MARX, 2002, p. 184).

O Decreto presidencial brasileiro de 04 de novembro de 2010, tem como base 05 princípios, que são importantes, e evidenciam o campodas suas articulações contrahegemônicas, compreendendo uma simetria com as Diretrizes Operacionais para a 
educação nas escolas do campo de 2002. É uma referência signatária, apesar de não ser a Lei socialmente desejável pelos movimentos socias, pelo aspecto de sua natureza, de ser um Decreto; mas, dialeticamente, como destaca Munarim (2011), este é inerente a afirmação de espaço para desenvolvimento e continuidades de articulações democráticas para a política ideal se tornar concretude, uma vez que a luta de classes se expressa na correlação de forças entre projetos societários da floresta e do campo brasileiro.

Este documento está constituído de 19 Artigos, o qual representa continuidade de avanços na legislação para formulação de políticas educacionais para os povos do campo, ensejando que os sistemas de ensino valorizem a relação da escola com a sociedade, nesta, a relação entre saberes tradicionais e escola. Numa perspectiva histórico-critíca como é necessário trabalhar o Decreto 7.352/2010 como elemento central, por meio dos significados dos elos de seus eixos estruturados e estruturantes de políticas públicas com as demais dimensões da realidade, econômica, social, cultural, a fim de que este não seja apropriado pelo encanto às novas tecnologias e"novas" idéias" pedagógicas, de modo a contribuir ao esvaír do conhecimento sistematizado, e seja indutor de propostas concretas.

O Decreto, no seu Art. $1^{\circ}$, parágrafo $1^{\circ}$, inciso II, destaca o conceito de " escola do campo: aquela situada em área rural, conforme definida pela Fundação Instituto Brasileiro de Geografia e Estatística -IBGE, ou aquela situada em área urbana, desde que atenda predominantemente as populações do campo. Essa definição como assinala Munarim (2011) se revela embasadora para acesso ao financiamento regular às escolas do campo, uma vez que situa o lugar da educação do campo, seus horizontes e fins para os filhos de seus trabalhadores, e, a enfatiza para além da definição tradicional urbano/rural. Nessa conquista, as escolas que atendem alunos do campo, poderão receber recursos financeiros específicos que esses alunos têm direito. Isto pressupõe a exigência do rigor de serem seguidos os critérios e condições efetivas para a educação de qualidade social.

Outro ponto é o princípio II que expressa a valorização da pesquisa, quando pontua o incentivo à investigação e estudos sobre o desenvolvimento social em âmbito regional e local, a partir de metas do Projeto político pedagógico. O PP ganha espaço próprio, a medida que os movimentos sociais compreendem que este é a vida escolar; a ele cabe dar inovação no planejamento da formação, para além de aspectos emergenciais. Assim, a abertura para com a produção do conhecimento, a partir do ensino básico representa participação democrática da sociedade civil e abertura de gestão democrática, com corlário às ações de Conselhos escolares com função de deliberativa. Assim, em seu Art. $2^{\circ}$ são princípios da educação do campo:

I -respeito à diversidade do campo em seus aspectos sociais, culturais, ambientais, políticos, econômicos, de gênero, geracional e de raça e etnia;

II -incentivo à formulação de projetos político-pedagógicos específicos para as escolas do campo, estimulando o desenvolvimento das unidades escolares como espaços públicos de investigação e articulação de experiências e estudos direcionados para o desenvolvimento social, economicamente justo e ambientalmente sustentável, em articulação com o mundo do trabalho;

Nesse artigo, marcos para incluir na organização curricular temáticas, como a diversidade cultural, étnica, geracional e de gênero, para além de discussões pontuais, como forma de tais dimensões serem objeto de diálogo e reflexão. Esse aspecto pressupõe que a formação humana precisa ser referenciada no contexto histórico-social, assim, ensino, pesquisa e extensão são dimensões inter-relacionadas no ato educativo; ademais, 
que a indissociabilidade entre teoria e prática é um componente basilar para se ter indivíduos capazes de pensar e agir nas relações sociais.

Pensar educação escolar em todos espaços, níveis e modalidades, a partir de idéias que movimentos sociais, como o MST defende, em que as dimensões da realidade são interdependentes: História, educação, cidadania e direitos humanos. Acesso e permanência à vida social, implica em que os direitos sejam acessados, nesse sentido, direito à terra, escola, saúde, moradia, ao trabalho, emprego, cultura,entre outros básicos, para as pessoas viverem e decidirem em que espaço.

Estudiosos da educação do campo, como Molina; Mançano Fernandez (2004), apontam um diganóstico geral, a distorção idade/série, condições precárias de infraestrutura das escolas, descontinuidade na formação e inserção de professores nas redes de ensino públcias, alocação de escolas nas residências de professores, entre outros problemas, como o fechamento de escolas do campo - problemática denunciada pelos movimentos sociais. Tais escolas, como assinalou Felipe (2011), não interessa ao setores dominantes. O campo é constituído de projetos societários distintos, diferentes nos meios e nos seus fins, mediado pelo conflito, tensão e contradições, desigualdades sociais.

Essas desigualdades se expressam no planejamento e operacionalidade de políticas sociais, como as educacionais, salariais, que conduzem a impactos sociais potencializadores de desigualdades, com partida, permanência e sucesso diferenciado/precário na educação infantil, fundamental e acentuação no ensino médio, e mais distante ainda da inclusão no superior. Qual a condição de oferta da educação escolar no campo? Por quê a média diferencial de anos de escolaridade entre a população do campo e a da cidade? Qual o valor social que o Estado e a família e o jovem desse espaço atribuem a escola? Qual controle da educação escolar do campo? O porque do controle social?

Pensar a educação do campo no sentido de inclusão social, em movimento contrahegemônico ao ideário do sistema capitalista, exige, discordar de políticas sociais presenteístas, que optam pela priorização de programas que centram na avaliação em si mesma, de produtos, vinculadas ao mercado, como planos de aceleração da aprendizagem. Valores referenciais étnico-culturais, identitários são secundarizados, emergindo, como registrou Guarani (2011), um genocídio etno-cultural, além do detrimento da formação integral. Isto se expressa pela própria Lei, como a 11.079/04, que regulamenta a parceria entre público e privado; nesse sentido qual é a saída para educação integrada? Quem define as regras do planejamento e da operacionalidade da educação?

\section{PL PNE 8035/010: PRIMEIRA INCURSÃo À EDUCAÇÃO DO CAMPO}

O texto do Projeto de Lei 8.035/2010, de 15 de dezembro de 2010; está estruturado em 02 partes. A primeira parte consiste na apresentação dos doze Artigos, que orientam a Organização da Política Educacional, decorrente do PNE e tratam de algumas diretrizes para a sua operacionalidade e elaboração de novos planos regionais e municipais de educação.

O seu Artigo $1^{\circ}$ insere a aprovação do PNE como instrumento normativo da União para legislar como referência central na condução da Educação brasileira: "[...] Fica aprovado o Plano Nacional de Educação para o decênio 2011-2020 (PNE - 2011/2020) constante do Anexo desta Lei, com vistas ao cumprimento do disposto no Art. 214 da Constituição".

A segunda parte trata das metas e estratégias, organizada na forma de anexo. Esta parte contém 20 metas e 170 estratégias, que discorrem sobre a ordenação da educação. As 
metas estão relacionadas com os níveis e modalidades de ensino, de forma a abranger, A educação Básica e Superior. Tais metas incluem a educação infantil, ensino fundamental, médio, superior e pós-graduação, bem como as modalidades de educação de Jovens e Adultos, profissional, Indígena, Ambiental e Indígena. As estratégias estão organizadas próximas aos níveis e modalidades, mas de forma que algumas estratégias são de natureza de metas.

Nesta primeira e breve análise pode-se considerar que o Projeto do Plano Nacional de Educação atual é limitado por não apresentar um diagnóstico sobre as demandas sociais da Educação e sua política, que necessitam ser consideradas e incluídas. Este é constituído de forma sucinta, compreendendo uma apreensão panorâmica, que expressa em parte, metas e estratégias, discutidas na Conferencial Nacional de Educação - CONAE-2010. O Plano, ao decorrer do enunciado das estratégias tem uma característica geral, não definindo elementos concretos para a exeqüibilidade financeira, uma vez que se deve considerar na política e gestão da educação questões estruturais e conjunturais na relação, Estado e Educação. Este toma como parâmetro o IDEB, todavia é necessário considerar para além de sua média, na medida que, esta nem sempre dá conta dos indicadores de desenvolvimento da educação; o tensionamento ultrapassa uma determinada relação, o que exige compreender as inter-relações entre os entes federados e a sociedade civil, e os modelos de avaliação para educação. Isto exige que a lógica patrimonial e da descontinuidade seja cessada, o que compreende mudanças no âmbito executivo, principalmente, para evitar a manutenção do padrão de financiamento. Padrão esse ancorado num horizonte de políticas governamentais específicas, como FUNDEF e FUNDEB.

Entre as 20 metas e suas estratégias, com média de 10 estratégias para cada, é situada a educação do campo, em cerca de quase $50 \%$ dessas, ausentes e/ou indiretamente contempladas nas de número $5,9,10,13,16,17,18,19$ e 20 . O universo é de 37 estratégias para educação do campo. A média de inclusão de estratégias para a educação do campo é de 01, destacando-se 04 estratégias na meta 02; metas essas que tratam de uma demanda consoante aos interesses dos setores dominantes, já signatárias nas Conferências Internacionais de Educação para Todos, como a de Jontien, em março de 1990, "Universalizar o ensino fundamental de nove anos para toda população de 6 a 14 anos".

Refletir sobre as metas implica em se posicionar também quanto a Educação como Direito Social e responsabilidade do Estado, essa como conquista e não concessão. Desse modo, analisar a política educacional nas interfaces com as demais políticas públicas no processo de mundialização do capital é considerar a educação enquanto aporte base, sólido para o desenvolvimento humano. Isso exige apreender suas intra e inter-relações, incluindo as relações internacionais no contexto da economia política e da cultura escolar em que organismos internacionais se articulam para a atualidade no sistema capitalista.

$\mathrm{O}$ contexto e inter-texto exige que se tenha um olhar para o movimento desses sujeitos, nos seus planejamentos e operacionalidades e sua concepção sobre educação; o que inclui a tipologia de educação: educação integral ou em serviço. Nessa relação, quais as funções do Banco Mundial, OMC, BID, entre outros, no debate sobre a política educacional brasileira. Em relação à educação do campo, no nível infantil, meta 01, cabe inseri-lo, como espaço necessário a sua implementação e expansão, uma vez que não está localizada nas estratégias, apesar de ter sido inserida a educação indígena. Defender a educação como direito social, exige também a proposta de que a educação infantil, nessa a educação do campo, seja realizada em sistemas públicos e não confessionais, como assinala o ANDES (2011). 
A meta 02, na estratégia 2.4, trata da questão de ampliação de Programa de aquisição de transporte, pontuando a demanda social sobre esse déficit histórico do transporte escolar intracampo. Tal demanda é construída no âmbito das CONAEs regionais, uma vez que a problemática é enfrentada pela população do campo. Para isso, é importante refletir sobre o déficit de escolas nas localidades distantes das regiões brasileiras, como a Amazônia, e as desigualdades intra-regionais, e atualidade da prioridade invertida, o uso do transporte campo cidade, conduzido pela maioria dos gestores municipais.

Essa meta também trata da questão da diversidade da organização curricular e do calendário escolar, da implantação de rede de computadores e cultura digital, eletrônica. Para tal é importante que esteja detalhado na meta do financiamento, mas, esta tem uma escrita genérica. A pertinência é indiscutível para o acesso e democratização às tecnologias, no entanto, a expansão/manutenção dos prédios da escola pública, não está incluída em nenhuma das metas, Assim, condições estruturais de uma cultura política de vitalização das escolas do campo, em termos de infra-estrutura de qualidade, para garantir o acesso e uso com continuidade é ausente. Como implementar tais equipamentos, em prédios de escolas de uma ou duas salas, que não detêm espaço e nem instrumental didático adequado, pelo menos uma cozinha, biblioteca, quadra de esportes, energia, instrumental eletrônico, se o processo educacional se realiza com tecnologia do mimeógrafo? Como exemplo, cita-se, os equipamentos e computadores, no Estado do Pará chegaram, e estiveram em 2008, na escola Estadual Magalhães Barata, na Vila de Americano, e/ou ainda estão, esperando tal espaço; cenário possível em muitas outras escolas de educação básica. Mesmo considerando o que prevê a estratégia 4.2, que dispõe sobre a implantação de salas com material de multimídias, deve ser considerado além; ademais: escolas do campo necessitam é de reforma geral dos prédios, face as suas precariedades.

A estratégia 6.6, que visa atender as escolas do campo em tempo integral é uma demanda histórica, todavia, na atualidade da política de nucleação, em que, entre os anos de 2000 e 2008, foram fechadas mais de 30 mil escolas rurais, é um grande desafio superar tal déficit, em função de que muitas crianças estão estudando em lugares distantes de sua casa/localidade, enfrentando um tempo de mais de duas horas de viagem diárias, em condições precárias e sem segurança, como caminhões, barcos, canoas, camionetes, para simultaneamente, estarem presentes no labor do trabalho na agricultura e/ou agroextrativismo. Escola do tempo integral é vinculada ao direito de se ter condições de acesso, permanência e sucesso nos estudos, com qualidade social, e não de serviços.

A Meta 7, estratégia 17, visa“Ampliar a educação escolar do campo, quilombola e indígena a partir de uma visão articulada ao desenvolvimento sustentável e à preservação da identidade cultural". Esta assegura a temática ambiental e de políticas de desenvolvimento na organização curricular das escolas do campo, entretanto, convém lembrar, qual a concepção de desenvolvimento que será trabalhada? Na perspectiva, histórico-crítica, ou liberal da educação? O caráter dos conteúdos e da discussão é imprescindível, para todas as temáticas e em todos os níveis e modalidades de ensino; assim, no processo educacional qual desenvolvimento que se defende na formação discente e docente? O de que substitui o conceito de progresso pelo de desenvolvimento sustentável em si mesmo, sem aportes de uso racional dos materiais naturais? Ou o que tem como base as lógicas de tecnologias de povos tradicionais, camponeses, indígenas quilombolas, com base no valor de uso? Defende-se este último, pelos seus princípios de garantir a sustentabilidade ambiental e estar próximo ao desenvolvimento social, e sua incursão no currículo da Educação Básica e Superior do Campo. 
Esta meta 07 tem centralidade pela sua própria forma redacional ser diretiva a uma tipologia de indicador para fazer mediação e base para avaliação do desenvolvimento educacional, por isso sintética, na exposição de concepções, avaliações, carência de organicidade. Como registra Dourado (2011), não são delineadas novas relações e responsabilidades de entes federados. Isso é fundamental, em função de um contexto marcado pela situação de guerras fiscais. Como esse processo vai se ocorrer no local? Que respaldo terá no município? Importante é estar atento, e reivindicar outro quadro, para superar o atual de déficit histórico à Educação Infantil e ao Ensino Médio. Fato que se configura num grande desafio para sua realização e universalização; mais profundo nos campos e florestas. Vinculados ao eixo estruturante da Política educacional, o financiamento. Quem pagará as contas?

A Educação superior no movimento conjuntural de políticas neoliberais, que foram introduzidas nos governos brasileiros, na década de 1990, tem continuidade, na primeira década do século XXI, expressando-se pelo viés social dos programas educacionais que beneficiam os setores educacionais privados. Destaca-se nesse cenário o retraimento percentual de matrículas nas universidades públicas: “[...] Pós anos 60. Partindo de um patamar de $60 \%$ de matrículas em IEs públicas, passou, em meados dos anos 90 , para $40 \%$ e termina o decênio, do PNE passado com $25 \%$ no geral, e de apenas 105, no Estado de São Paulo, de matrículas nessa esfera [...]" (ANDES, 2011). Cenário favorável à ES em faculdades privadas, que se revela por meio do PROUNI, com rigor de primar pelo financiamento, via FIES; este colocado próximo às estratégias 12.6; 15.2; 14.3 e 11.6 do PL 8.035. Essa aproximação até que ponto beneficiará a Educação Superior no Campo, apesar desta estar timidamente pontuada no seu texto; é inserida nos limites das políticas afirmativas, e delimitada proporcionalmente. Necessidades históricas dos povos do campo e floresta são para além de Programas como PRONERA e da cultura política das cotas. Essa forma de contemplação compromete à operacionalidade das conquistas contidas no Decreto 7.352/ 2010.

Na meta 20, não há proposição efetiva e detalhada de 7\%,clareza nas definições de responsabilidades, origem dos recursos financeiros, nem maior incidência de $10 \%$ garantidos via PIB. Enquanto tramita o processo, apesar de esforços de muitos setores na elaboração de emendas, que avançam no campo do financiamento, e de todo o trabalho das Conferências Regionais de Educação, ao longo de 2009, e da CONAE em 2010, há articulações extremadas, dos atores privatistas, que apostam na ineficiência do PNE. O horizonte em tempo longo e de caráter estrutural no PNE, como assinala SAVIANI (2008), que seja central e não em disputas com outras áreas socais está por vir, na educação e sua encruzilhada no debate do parlamento. Enquanto o governo trabalha com a perspectiva do prover, com recursos de 50\% do Programa Pré-sal, via criação de Fundo Social, sinaliza para uma concretude, estimada, a partir de 2015, quando, o Programa terá tempo de retorno, isto à base da exploração da natureza. A correlação de forças é uma das esperanças, para superar estratégias dos representantes da sociedade do conhecimento.

\section{CONCLUSÃO}

O Quadro que se desenha frente ao PL 8.035/2010 é de déficits históricos à educação do campo, que este, na sua proposição inicial não deu conta. Os desafios são enormes para superar a tradição patrimonial e clientelista do Estado Brasileiro, que coexiste com desigualdades sociais e se potencializa como a $7^{\mathrm{a}}$ ou $8^{\mathrm{a}}$ economia mundial, em cenários nos níveis regionais e inter-regionais. Implica a necessidade de identificar tensões e problematizar para além da média do IDEB, apesar de ser um indicador 
importante. Vale considerar que a lógica de políticas educacionais não é a lógica de descontinuidade.

Indicadores da sociedade apontam a necessidade de fortalecimento da gestão democrática, a partir de Conselhos escolares. Objeto de crítica à política educacional é a gestão regulada. Esta necessita ser mediada pelo PNE democrático, em defesa da escola e educação pública, enquanto hegemônicas aos interesses da sociedade; este tendo como princípio educativo à pesquisa e o trabalho. Como assinala Dourado (2011), o Governo do presidente Luis Inácio Lula da Silva deu prioridade ao PDE e não ao PNE, este como plano de gestão. Na atualidade, é necessário fomentar o debate para apreender movimento real. Cabe refletir debruçadamente sobre qual inter-relação do PNE, para garantir a Lei de responsabilidade da educação, seu financiamento seguro, gestão democrática, plano de carreira do professor e inclusão, para escolas do campo e da floresta.

O horizonte vislumbrado é em dimensão de médio e longo prazo, para se ter políticas que instaurem, não dicotomias, conceitos ideologizados no campo do pseudouniversal, ou dos específicos em si mesmos, mas sim, como campos que sejam embasados nos movimentos conjunturais e estruturais, de resistência ativa (SAVIANI, 2007), que se expressa para além da lógica formal capitalista, a lógica que expressa a instauração de sociabilidades éticas, com inclusão, a partir de relações sociais construídas no processo histórico.

Nesse sentido, o PNE deve ser eixo orientador da políticas educacionais. Sua lógica, no PL tem limites, que necessitam serem superados, tanto em seus Artigos, metas e diretrizes, para se aproximar ao que estabelece a Constituição Federal sobre educação, e não aquém.

\title{
9. REFERÊNCIAS
}

\section{ORAL}

\author{
Almires Guarany \\ Eliana Felipe \\ Luiz Dourado
}

\section{DOCUMENTAL}

ANDES. Análise do Projeto de Lei 8.035/2010. www.andes.org.br,29 de março de 2011.

BRASIL/PRESIDÊNCIA DA REPÚBLICA-CASA CIVIL/SUB-CHEFIA PARA ASSUNTOS JURÍDICOS. Decreto $\mathbf{n}^{\mathbf{0}} \mathbf{7 . 3 5 2} / \mathbf{2 0 1 0}$. Dispõe sobre a política de educação do campo e o Programa Nacional de Educação na Reforma Agrária, de 4 de novembro de 2010.

BRASIL/MEC. Lei de Diretrizes e Bases 9394/96, Brasília, DISTRITO FEDERAL, 1996.

BRASIL/MEC. Diretrizes operacionais para a educação básica nas escolas do Campo. Resolução CNE/CEB nº 1, de 3 de abril de 2002, 2003.

Referências para uma política nacional do campo. Caderno de subsídios.Brasília, DISTRITO FEDERAL: MEC, 2004.

BRASIL/MEC.Plano Nacional de educação para todos.Brasília (DF):MEC, 1993.

BRASIL/Ministério da Educação e Cultura. Instituto Nacional de Estudos e Pesquisas Educacionais Anísio Teixeira. Distorção idade/série: Ensino Fundamental no Pará. Brasília, DF, 2006. 
Estabelecimentos com ensino Fundamental - Ano 2005, no Estado do Pará. Brasília, DF, INEP, 2006.

Estabelecimentos com educação Infantil - ano 2005, no Estado do Pará. Brasília, DF, 2006.

BRASIL. Ministério da Educação e Cultura. Secretaria de educação Continuada, Alfabetização e Diversidade. Seminários estaduais. Educação e diversidade no campo. Folheto de divulgação. Brasília, Distrito Federal, 2004.

BRASIL. Ministério de Educação e Cultura. www.mec.gov.br/sef/fundef, acessado em 2006.

BRASIL. Ministério de Educação e Cultura. (de 20 de dezembro de 1996) LEI DE DIRETRIZES E BASES 9394/96, Brasília, DF, 1997.

BRASIL/MEC. Diretrizes Operacionais para a educação básica nas escolas do Campo. Resolução CNE/CEB nº ${ }^{\circ}$, de 3 de abril de 2002, 2003.

BRASIL/MEC/CNE. Diretrizes Operacionais para a educação básica nas escolas do Campo. Parecer n. 36/2001. Resolução CNE/CEB n. 1, de 3 de abril de 2002, 2003.

BRASIL/MEC. Plano Nacional de Educação para Todos. Brasilia: MEC, 1993.

BRASIL/MEC. Referências para uma Política Nacional do Campo. Cadernos de Subsídios. Brasília: MEC/SECRETARIA DE EDUCAÇÃO CONTINUADA, ALFABETIZAÇÃO e DIVERSIDADE/Grupo Permanente de Trabalho de Educação do Campo, 2004.

BRASIL. Governo Federal. Constituição Federal da República Brasileira. Brasília, DF, 1988.

COMISSÃO NACIONAL DOS BISPOS DO BRASIL et al. Declaração Final. In: II CONFERÊNCIA NACIONAL POR UMA EDUCAÇÃO DO CAMPO. Por uma política pública de educação do campo, 8, 2004. Luziânia,GO: MST/MEC, 2004.

MOVIMENTO DOS TRABALHADORES SEM TERRA. Princípios da educação no MST. Caderno de Educação, São Paulo, nº 8, 1999.

\section{BIBLIOGRÁFICA}

ARROYO, Miguel; FERNANDES, Bernardo Mançano. A educação básica e o movimento social do campo. Col. Por uma educação básica do campo, $n^{\circ} 02$. Brasília (DF): Articulação Nacional por uma educação, 2000.

CABRAL NETO, Antônio. Política educacional: desafios e tendências. Porto Alegre, RS: Sulina, Natal, Rio Grande do Norte:UFRN, 2004.

CALDART, Roseli Salete. Escola é mais do que Escola na Pedagogia do Movimento Sem Terra.2 ${ }^{\text {a }}$.ed, Rio de Janeiro: Vozes, 2000.

. Formação de identidade. Pedagogia da Terra. Veranópolis, Rio Grande do Sul: ITERRA, 2002.

CALDART, Roseli Salete.Elementos para construção do projeto político e pedagógico da Educação do campo. In: SEMINÁRIO ESTADUAL DE EDUCAÇÃO DO CAMPO, 2004. Curitiba. Anais. Curitiba,PR: [s.n.], 2004.Texto digitado, 2004. 
CALAZANS, Julieta. Apresentação. In: GONÇALVES, Maria Alice Rezende. Educação e Cultura. Pensando em cidadania.. Rio de Janeiro: Quartet, 1999. (Col. Educação e Sociedade).

CALAZANS, Julieta; SILVA, Hélio Raimundo Santos. Retrospectiva da Educação Rural no Brasil. In: SEMINÁRIO DE EDUCAÇÃO RURAL NO BRASIL - 1982. Anais. Brasília, Distrito Federal: INEP, 1983.

COSTA, Messias. A Educação nas Constituições do Brasil. Dados e Direções, Rio de Janeiro: 2002.

DUARTE, Newton. Sociedade do conhecimento ou sociedade das ilusões? Campinas, SP: Autores Associados, 2003. (Col. Polêmicas do Nosso Tempo).

FERNANDES, Bernardo Mançano. Diretrizes de uma caminhada. In: KOLLING, Edgar Jorge; CERIOLLI, Paulo Ricardo; CALDART, Roseli Salete. Educação do campo: identidade e políticas públicas. São Paulo: ANCA, 2002, p. 37-46.

FRIGOTTO, G.; CIAVATTA Maria. Educação básica no Brasil na década de 1990: subordinação ativa e consentida à lógica do mercado.In: Revista Educação e Sociedade.São Paulo: CEDES, 2002, p. 93-132.

GERMANO, José Willington. Educação e Ajuste Neoliberal. Reforma do Estado, Universidade, Governação. IN: GICO, Vânia, SPINELLI, Antônio e VICENTE, Pedro (Orgs). As Ciências Sociais: desafios do milênio, Natal: UFRN, 2001.

GRAMSCI, Antônio. Os Intelectuais e a organização da cultura. Trad. de Carlos Nelson Coutinho. 4. ed. Rio de Janeiro: [s.n], 1982.

KOLLING, Edgar Jorge; CERIOLI, Paulo Ricardo; CALDART, Roseli Salete. (orgs). Educação do Campo: Identidade e políticas públicas. Col. Por uma educação do campo, n 4. Brasília (DF): Articulação Nacional por uma Educação do Campo, 2002.

LEITE, SÉRGIO CELANI. Escola rural: urbanização e políticas educacionais. São Paulo, Cortez, 1999.

Marx, Karl. Manuscritos econômicos e filosóficos. Trad. D Alex Martins. São Paulo, Martin Claret, 2002.

MARTINS, José de Souza. Exclusão social e a nova desigualdade. São Paulo: Paulus, 1997.

MUNARIM, Antônio. A educação do campo na atual conjuntura. Florianópolis, Santa Catarina: UFSC, 2011, digitado.

OFFE, Claus. Sistema educacional, sistema ocupacional e política da educação Contribuição à determinação das funções do sistema educacional. Tradução de Vanilda Paiva. Revista Educação e Sociedade, n 35, abril de 1990. São Paulo, n. 35, p. 9-59, CEDES, abr.1990.

PERRONI, Política educacional e papel do Estado no Brasil dos anos 1990. São Paulo: Xamã, 2003.

Reis, Neila da Silva. Educação do campo e alternância: reflexões sobre uma experiência na Transamazônica, 2000-2005.Tese de doutoramento. Natal, Rio Grande do Norte: UFRN, 2006. Orientador: Prof. Dr. JOSÉ WILLINGTON GERMANO, digitado. 
RIBEIRO, Renato Janine. A sociedade contra o social. O alto custo da vida pública no Brasil. São Paulo: Companhias da Letras, 2000.

ROSAR, Maria de Fátima FÉLIX; KRAWCZYC, Nora Rut. Diferenças da homogeneidade: Elementos para o estudo da política educacional na América Latina. IN: Revista Educação \& Sociedade. Dossiê Políticas educacionais. Campinas São Paulo: Ano XXII, nº. 75, agosto, 2001, p. 33-47.

SAVIANI, Dermeval. Da nova LDB ao FUNDEB. São Paulo: Autores Associados, 2007. 2008 .

História das idéias Pedagógicas no Brasil. $5^{\mathrm{a}}$ ed. São Paulo: Autores Associados,

SOARES, Edla Lira. Parecer sobre as Diretrizes operacionais para a educação básica nas escolas do campo. IN: KOLING, Edgar Jorge: CERIOLI Paulo Ricardo; CALDART, Roseli Salete (Orgs). Identidade e Políticas Públicas. Col. Por uma educação básica do campo, $\mathrm{n}^{\circ}$ 4. Brasília (DF): Articulação nacional por uma educação do Campo, 2002.

SHIVA, Vandana. Monoculturas da Mente. Perspectivas da biodiversidade e da biotecnologia.São Paulo: Gaia, 2003.

Recebido em: 30/06/2011

Aprovado em: 25/07/2011

Revista HISTEDBR On-line, Campinas, número especial, p. 124-148, out2011 - ISSN: 1676-2584 